Dept. of Clinical Studies,

Fac. of Vet. Science, University of Nyala, Sudan.

\title{
SOME ANAESTHETIC AND PHYSIOLOGICAL EFFECTS OF THIOPENTONE SODIUM IN GOAT KIDS
}

(With 5 Tables)

By

\section{M.A.H. GHURASHI; A.T.H. SOBAIR*; H.I. SERI and $A S H W A G$ E.A.M}

*Dept. of Surgery and Anaesthesia, Fac. of Vet. Med., University of Khartoum Sudan.

**Dept. of Physiology and Biochemistry Studies, Fac. of Vet. Science, University of Nyala, Sudan.

(Received at 1/9/2007)

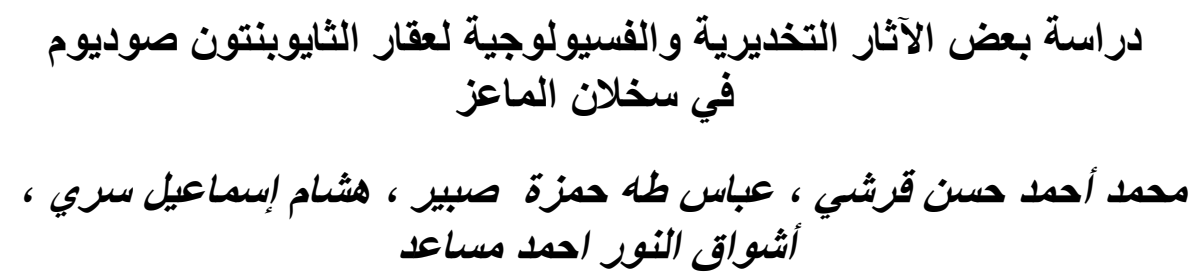

تم إجراء هذا البحث علي عدد 7 من سخلان الماعز المهجنة السليمة وذلك لدراسة الآثار

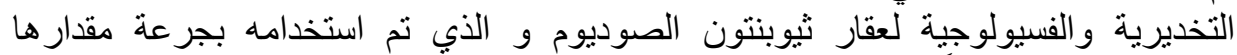

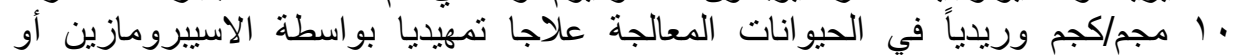

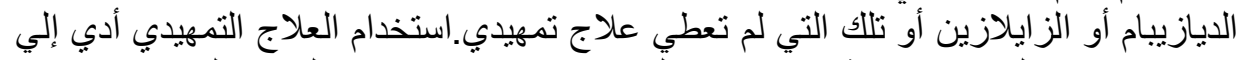

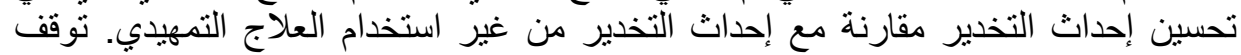

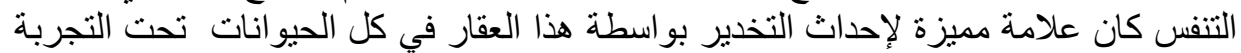

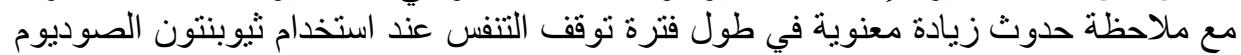

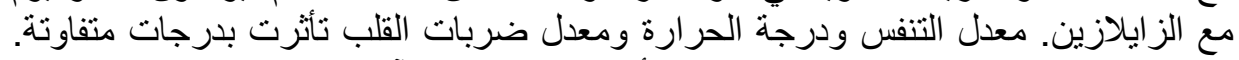
استخدام العلاج التمهيدي خاصة الزايلازين أدي إلي تحسين الآثار التخديرية لعقار ثيوبنتون الصوديوم.

\section{SUMMARY}

A total of six healthy goat kids were used in this investigation to study some physiological and anaesthetic effects of Thiopentone sodium at doe level of $10 \mathrm{mg} / \mathrm{kg} \mathrm{i} / \mathrm{v}$ in animals premedicated with acepromazine or diazepam or xylazine and non premedicated animals. Usages of premedication lead to smoother induction of anaesthesia rather than non 
premedicated animals. Apnoea occurred in the different groups used in this study with significant prolongation in the group anaesthetized with Thiopentone sodium with Xylazine. Respiratory rate, heart rate and rectal temperature were affected to different limits. Usage of the three different premedication drugs especially Xylazine hydrochloride lead to improvement of Thiopentone sodium anaesthetic effects.

Key words: Thiopentone sodium, Xylazine, Acepromazine, Diazepam, goat kids

\section{INTRODUCTION}

The importance of goats in many developing countries can be seen in their vital contribution in the production of meat, milk and fresh skin (Payne, 1994). In the Sudan the total population of goats is about 37.346 million head (SBAR, 2000) and they participate efficiently in the national income.

It has been established for many years that all surgical procedures are better be done under inhalation anaesthesia (Hall et al., 2006), should the facilities for it are available. However, the lack of such sophisticated and expensive inhalation machines particularly in the third world countries made the use of intravenous agents coupled with different pre-anaesthetic medications one of the few available options for short to medium term surgery. Being an ultra -short acting barbiturate, Thiopentone sodium, is a good induction agent producing anaesthesia for a very short duration (Hall and Clark, 1982; Singh and Kumar, 1988; and Batoul, 1990).

The aim of this study is to investigate some physiological and anaesthetic effects of Thiopentone Sodium at dose level of $10 \mathrm{mg} / \mathrm{kg}$ in goat kids and also to make an attempt to promote the anaesthetic effects through premedication.

\section{MATERIALS and METHODS}

\section{Animals}

A total of six healthy goat kids, two females and four males were used in this study. They are cross breed between Nubian and Saaneen, five to nine months of age weighing between 12 to 17 kilograms. They were kept in closed bens and fed with roughages and concentrates with free access to water.

Protocols of anaesthesia used: 
1 - Thiopentone Sodium $10 \mathrm{mg} / \mathrm{kg} \mathrm{i} / \mathrm{v}$ (TH)

2 - Thiopentone Sodium $10 \mathrm{mg} / \mathrm{kg} \mathrm{i} / \mathrm{v}+$ Acepromazine (2\%) $0.2 \mathrm{mg} / \mathrm{kg}$ $\mathrm{i} / \mathrm{v}(\mathrm{TH}+\mathrm{ACP})$

3 - Thiopentone Sodium $10 \mathrm{mg} / \mathrm{kg} \mathrm{i} / \mathrm{v}+$ Diazepam (10\%) $0.5 \mathrm{mg} / \mathrm{kg} \mathrm{i} / \mathrm{v}$ $(\mathrm{TH}+\mathrm{DZ})$

4 - Thiopentone Sodium $10 \mathrm{mg} / \mathrm{kg} \mathrm{i} / \mathrm{v}+$ Xylazine (2\%) $0.1 \mathrm{mg} / \mathrm{kg} \mathrm{i} / \mathrm{v}$ $(\mathrm{TH}+\mathrm{XY})$

Each of the above mentioned protocols was injected in same group of animals at one month interval between each two successive treatments for the purpose of washing out the residues of the drugs.

\section{Premedication}

The three pre-anaesthetic medications used in protocol 2, 3 and 4 were injected five minutes prior injection of the anaesthetic drug intravenously.

\section{Monitoring of the physiological and anaesthetic effects Physiological effects}

The respiratory rate, the heart rate and the rectal temperature were monitored using standard methods according to Kelly (1984).

\section{Anaesthetic effects}

This study was designed to investigate the following anaesthetic effects:

1 - Induction of anaesthesia which include induction time and induction characters. Induction of anaesthesia was determined by unconsciousness and disappearance of reflexes as described by (Jani et al., 1982)

2 - Phases of anaesthesia which include:

- Anaesthesia phase: was taken as the time during which the animal is unconscious, no reflexes and responding negatively to the external stimuli (Tamisto et al., 1981), the eternal stimuli used in this study were assessment of reflexes and/ or pin brick in the flank region.

- Basal narcosis phase: was taken as the duration in which the animal showed signs of unconsciousness but responding positively to external stimuli (Atkinson et al., 1987, Hall and Clark 1982), the external stimuli used in this study were assessment of reflexes and/ or pin brick in the flank region

- Lateral recumbancy phase: was taken as the phase during which the animal opened its eyes and the reflexes were regained but it is unable to adopt Sternal recumbancy position. 
- Sternal recumbancy phase: was taken as the time elapse during which the animal adopted sternal position but unable to stand.

- Standing phase: Was taken as the time during which the animal succeeded to adopt standing position but unable to walk for ten steps without falling.

- Recovery: The animal was considered to be recovered from anaesthesia when it was able to support itself in the standing position and walked for ten steps without falling.

\section{Statistical analysis}

The raw data of the respiratory rate, heart rate and rectal temperature were analyzed using one way ANOVA and taking the base line value as a control within the same group. The different phases of anaesthesia were compared with each other using one way ANOVA and taking Thiopentone sodium as a control group. The least significant difference was used to determine the significance.

\section{RESULTS}

\section{Induction of anaesthesia}

The three groups treated with the protocols that contain premedication showed smooth induction, while the non premedicated group showed rough induction which shown by prompt falling of the animal to the ground. The four protocols used in this investigation resulted in non - significantly different durations of induction time (Table1).

\section{Apnoea}

Induction of anaesthesia with the protocol of $\mathrm{TH}+\mathrm{XY}$ resulted in a significantly longer duration $(\mathrm{P} \leq 0.05)$ of apnoea compared with the other protocols used in this study (Table1)

\section{Respiratory rate}

Induction of anaesthesia with Thiopentone resulted in a significant $(\mathrm{P} \leq 0.05)$ increase in the respiratory rate this increase was observed 20 minutes after induction of anaesthesia.

Following induction of anaesthesia with $\mathrm{TH}+\mathrm{ACP}$ a significant $(\mathrm{P} \leq 0.05)$ increase in the respiratory rate was observed immediately after spontaneous respiration was regained (Table 3). A significant decrease in the respiratory rate was observed ten minutes after induction of anaesthesia with TH + DZ (Table 3).

As a result of induction of anaesthesia with $\mathrm{TH}+\mathrm{XY}$ a significant $(\mathrm{P} \leq 0.05)$ drop in the respiratory rate was observed 
immediately after spontaneous resumption of respiration and at 20 minutes after induction of anaesthesia (Table 3).

\section{Heart rate}

Induction of anaesthesia with $\mathrm{TH}$ resulted in a significant $(\mathrm{P} \leq 0.05)$ tachycardia ten min. after induction of anaesthesia, which persisted until full recovery was attained (Table 4).

A significant $(\mathrm{P} \leq 0.05)$ tachycardia was observed immediately after induction of anaesthesia with $\mathrm{TH}+\mathrm{ACP}$ and remained at such significantly high levels for 10 and $20 \mathrm{~min}$. after induction of anaesthesia (Table 4).

Usage of $\mathrm{TH}+\mathrm{DZ}$ as an induction agent resulted in a significant tachycardia at forty and fifty min. after induction of anaesthesia (Table 4).

Induction of anaesthesia with $\mathrm{TH}+\mathrm{XY}$ resulted in a significant tachycardia immediately after induction of anaesthesia (Table 4).

\section{Rectal temperature}

Induction of anaesthesia with the four protocols used in this study resulted in non-significant changes in the rectal temperature (Table 5).

\section{Anaesthetic effects}

\section{Anaesthesia phase}

Induction of anaesthesia with $\mathrm{TH}+\mathrm{DZ}$ or $\mathrm{TH}+\mathrm{XY}$ resulted in anaesthesia phase which was observed to be significantly longer than the anaesthesia phase resulted when $\mathrm{TH}$ or $\mathrm{TH}+\mathrm{ACP}$ were used for induction of anaesthesia (Table 2). Percentage of this phase to the total recovery time was observed to be greater in $\mathrm{TH}+\mathrm{DZ}$ and $\mathrm{TH}+\mathrm{XY}$ treated groups when compared to the other two groups (Table 2).

\section{Narcosis phase}

Induction of anaesthesia with $\mathrm{TH}+\mathrm{DZ}$ or $\mathrm{TH}+\mathrm{XY}$ resulted in narcosis phase which is significantly longer than that occurred when anaesthesia induced with TH or TH +ACP (Table 2), percentage of this phase in $\mathrm{TH}+\mathrm{DZ}$ or $\mathrm{TH}+\mathrm{XY}$ treated groups was observed to be greater than that observed in the other groups (Table 2).

\section{Lateral recumbancy phase}

Induction of anaesthesia with $\mathrm{TH}+\mathrm{XY}$ resulted in a significantly longer duration of lateral recumbancy phase when compared with that resulted when anaesthesia was induced with $\mathrm{TH}$ or $\mathrm{TH}+\mathrm{ACP}$ (Table 2), percentage of this phase was observed to be greater than that resulted when anaesthesia was induced with $\mathrm{TH}$ and lesser when anaesthesia was induced with $\mathrm{TH}+\mathrm{DZ}$ (Table 2). 


\section{Sternal recumbancy}

Induction of anaesthesia with $\mathrm{TH}$ resulted in a significantly longer duration of sternal recumbancy phase when compared with $\mathrm{TH}+\mathrm{ACP}$ or $\mathrm{TH}+\mathrm{XY}$ treated groups (Table 2).

\section{Standing time}

Non-significant changes were observed in the durations and percentages of this phase among the protocols tested (Table 2).

Total recovery time:

Induction of anaesthesia with $\mathrm{TH}+\mathrm{DZ}$ or $\mathrm{TH}+\mathrm{XY}$ resulted in total recovery time which significantly longer than that resulted when anaesthesia was induced with $\mathrm{TH}$ or $\mathrm{TH}+\mathrm{ACP}$ (Table 2).

Table 1: Duration of apnoea and induction time in goat kids following administration of thiopentone sodium.

\begin{tabular}{|l|c|c|}
\hline Protocol & Duration of apnoea (seconds) & Induction time (seconds) \\
\hline TH & $10.83^{\mathrm{a}} \pm 6.67$ & $15^{\mathrm{a}} \pm 6$ \\
\hline TH $+\mathrm{ACP}$ & $10.83^{\mathrm{a}} \pm 7.22$ & $17^{\mathrm{a}} \pm 4$ \\
\hline TH+DZ & $22.83^{\mathrm{a}} \pm 14.33$ & $17^{\mathrm{a}} \pm 5$ \\
\hline TH $+\mathrm{XY}$ & $77.83^{\mathrm{b}} \pm 25.4$ & $20^{\mathrm{a}} \pm 8$ \\
\hline
\end{tabular}

Different letters in the same column indicate significant difference $(\mathrm{P} \leq 0.05)$.

Table 2: Duration and percentage of the different anaesthetic phases in goat kids following administration of thiopentone sodium.

\begin{tabular}{|l|c|c|c|c|c|}
\hline \multicolumn{2}{|c|}{ Phase } & TH & TH + ACP & TH + DZ & TH + XY \\
\hline \multirow{3}{*}{ Anaesthesia } & Duration & $0.85^{\mathrm{a}} \pm 0.44$ & $3.83^{\mathrm{ab}} \pm 1.77$ & $10.83^{\mathrm{c}} \pm 3.43$ & $11.16^{\mathrm{c}} \pm 2.4$ \\
\cline { 2 - 6 } & $\%$ & 4.13 & 16.35 & 18.88 & 25.01 \\
\hline \multirow{3}{*}{ Narcosis } & Duration & $3.04^{\mathrm{a}} \pm 3.47$ & $5.05^{\mathrm{a}} \pm 1.72$ & $19.78^{\mathrm{b}} \pm 8.79$ & $17.88^{\mathrm{b}} \pm 5.73$ \\
\cline { 2 - 6 } & $\%$ & 24.52 & 23.48 & 37.25 & 27.00 \\
\hline $\begin{array}{l}\text { Lateral } \\
\text { Recumbancy }\end{array}$ & Duration & $4.63^{\mathrm{a}} \pm 0.93$ & $12.25^{\mathrm{ab}} \pm 5.02$ & $18.39^{\mathrm{b}} \pm 10.12$ & $18.57^{\mathrm{b}} \pm 3.90$ \\
\cline { 2 - 6 } $\begin{array}{l}\text { Sternal } \\
\text { Recumbancy }\end{array}$ & 22.53 & 52.3 & 34.63 & 25.69 \\
\hline \multirow{2}{*}{\begin{tabular}{l} 
Standing \\
\cline { 2 - 6 }
\end{tabular}} & Duration & $9.76^{\mathrm{a}} \pm 6.14$ & $1.43^{\mathrm{a}} \pm 1.06$ & $3.07^{\mathrm{a}} \pm 2.98$ & $1.06^{\mathrm{a}} \pm 1.06$ \\
\cline { 2 - 6 } & 47.49 & 6.10 & 5.78 & 20.43 \\
\hline $\begin{array}{l}\text { Total } \\
\text { Recovery }\end{array}$ & Duration & $0.27^{\mathrm{a}} \pm 0.17$ & $0.41^{\mathrm{a}} \pm 0.29$ & $1.03^{\mathrm{a}} \pm 0.9$ & $0.02^{\mathrm{a}} \pm 0.1$ \\
\cline { 2 - 6 } & $\%$ & 1.31 & 1.75 & 1.90 & 1.87 \\
\hline
\end{tabular}

Different letters in the same row indicate significant difference $(\mathrm{P} \leq 0.05)$. 
Table 3: Respiratory rate in goat kids following administration of thiopentone sodium.

\begin{tabular}{|l|r|r|r|r|r|r|r|r|c|}
\hline Protocol & \multicolumn{1}{|c|}{ Base } & \multicolumn{1}{c|}{5} & \multicolumn{1}{c|}{0} & \multicolumn{1}{c|}{10} & \multicolumn{1}{c|}{20} & 30 & 40 & 50 & 60 \\
\hline TH & $34.40 \mathrm{~b}^{\mathrm{a}}$ & $21.80^{\mathrm{a}}$ & $21.85^{\mathrm{a}}$ & $33.75^{\mathrm{ab}}$ & $58.66^{\mathrm{b}}$ & & & & \\
& \pm 16.2 & \pm 7.7 & \pm 7.7 & \pm 11.42 & \pm 8.69 & & & & \\
\hline TH+ACP & $45.25 \mathrm{a}^{\mathrm{b}}$ & $25.62^{\mathrm{a}}$ & $68.85^{\mathrm{b}}$ & $29.25^{\mathrm{a}}$ & $35.75^{\mathrm{a}}$ & & & & \\
& \pm 14.54 & \pm 8.12 & \pm 5.46 & \pm 7.98 & \pm 5.93 & & & & \\
\hline TH+DZ & $32.37^{\mathrm{b}}$ & $27.6^{\mathrm{b}}$ & $21.5 \mathrm{a}^{\mathrm{b}}$ & $14.25^{\mathrm{a}}$ & $24.7^{\mathrm{b}}$ & $28.2^{\mathrm{b}}$ & $28.8^{\mathrm{b}}$ & $37.6^{\mathrm{b}}$ & $40.66^{\mathrm{b}}$ \\
& \pm 6.81 & \pm 8.74 & \pm 9.8 & \pm 6.19 & \pm 6.8 & \pm 10.3 & \pm 10.1 & \pm 11.2 & \pm 11.81 \\
\hline TH+ZY & $24.62^{\mathrm{b}}$ & $20.12^{\mathrm{b}}$ & $10.12^{\mathrm{a}}$ & $20.87^{\mathrm{b}}$ & $9.37^{\mathrm{a}}$ & $18.75^{\mathrm{b}}$ & $27.6^{\mathrm{b}}$ & $30.75^{\mathrm{b}}$ & \\
& \pm 3.67 & \pm 2.75 & \pm 3.82 & \pm 4.84 & \pm 3.77 & \pm 4.65 & \pm 8.59 & \pm 9.83 & \\
\hline
\end{tabular}

Different letters in the same row indicate significant difference $(\mathrm{P} \leq 0.05)$.

Table 4: Heart rate in goat kids following administration of thiopentone sodium.

\begin{tabular}{|l|l|l|l|l|l|l|l|l|l|}
\hline Protocol & \multicolumn{1}{|c|}{ Base } & \multicolumn{1}{c|}{5} & \multicolumn{1}{c|}{0} & \multicolumn{1}{c|}{10} & \multicolumn{1}{c|}{20} & 30 & 40 & 50 & 60 \\
\hline TH & $79.5^{\mathrm{a}}$ & ---- & $105.75^{\mathrm{b}}$ & $124^{\mathrm{b}}$ & $140.33^{\mathrm{b}}$ & & & & \\
& \pm 10 & & \pm 15.31 & \pm 19.87 & \pm 31.3 & & & & \\
\hline TH+ACP & $114.3^{\mathrm{a}}$ & $130.25^{\mathrm{ab}}$ & $148.37^{\mathrm{b}}$ & $\begin{array}{l}150.75^{\mathrm{b}} \\
147.5^{\mathrm{b}}\end{array}$ & & & & \\
& \pm 9.82 & \pm 18.2 & \pm 14.13 & \pm 19.63 & \pm 10.33 & & & & \\
\hline TH+DZ & $124.75^{\mathrm{a}}$ & $121^{\mathrm{a}}$ & $130.12^{\mathrm{a}}$ & $131.87^{\mathrm{a}}$ & $135.37^{\mathrm{a}}$ & $146.5^{\mathrm{a}}$ & $160.5^{\mathrm{b}}$ & $168^{\mathrm{b}}$ & $129.3^{\mathrm{a}}$ \\
& \pm 13.81 & \pm 32.44 & \pm 24.4 & \pm 24.55 & \pm 24.65 & \pm 28.8 & \pm 13.6 & \pm 25.42 & \pm 12.0 \\
\hline TH+ZY & $96.37^{\mathrm{a}}$ & $77.5^{\mathrm{a}}$ & $129.37^{\mathrm{b}}$ & $94.5^{\mathrm{a}}$ & $97.57^{\mathrm{a}}$ & $97.5^{\mathrm{a}}$ & $101.6^{\mathrm{a}}$ & $98.75^{\mathrm{a}}$ & \\
& \pm 16.26 & \pm 18.8 & \pm 13.03 & \pm 10.13 & \pm 6.58 & \pm 17.3 & \pm 18.21 & \pm 18.1 & \\
\hline
\end{tabular}

Different letters in the same row indicate significant difference $(\mathrm{P} \leq 0.05)$.

Table 5: Rectal temperature in goat kids following administration of thiopentone sodium.

\begin{tabular}{|l|c|c|c|c|c|c|c|c|c|}
\hline Protocol & Base & 5 & 0 & 10 & 20 & 30 & 40 & 50 & 60 \\
\hline TH & $39.6^{\mathrm{a}}$ & $39.0^{\mathrm{a}}$ & $39.7^{\mathrm{a}}$ & $39.6^{\mathrm{a}}$ & $39.5^{\mathrm{a}}$ & & & & \\
& \pm 0.54 & \pm 0.54 & \pm 0.55 & \pm 0.40 & \pm 0.35 & & & & \\
\hline $\mathrm{TH}+\mathrm{ACP}$ & $39.81^{\mathrm{a}}$ & $40.0^{\mathrm{a}}$ & $40.0^{\mathrm{a}}$ & $40.0^{\mathrm{a}}$ & $40.22^{\mathrm{a}}$ & & & & \\
& \pm 0.35 & \pm 0.36 & \pm 0.33 & \pm 0.42 & \pm 0.22 & & & & \\
\hline $\mathrm{TH}+\mathrm{DZ}$ & $39.85^{\mathrm{a}}$ & $39.82^{\mathrm{a}}$ & $39.8^{\mathrm{a}}$ & $39.75^{\mathrm{a}}$ & $39.8^{\mathrm{a}}$ & $39.78^{\mathrm{a}}$ & $39.8^{\mathrm{a}}$ & $40.0^{\mathrm{a}}$ & $39.24^{\mathrm{a}}$ \\
& \pm 0.23 & \pm 0.18 & \pm 0.2 & \pm 0.16 & \pm 0.26 & \pm 0.28 & \pm 0.35 & \pm 0.6 & \pm 0.24 \\
\hline $\mathrm{TH}+\mathrm{ZY}$ & $39.56^{\mathrm{a}}$ & $39.6^{\mathrm{a}}$ & $39.63^{\mathrm{a}}$ & $39.4^{\mathrm{a}}$ & $39.28^{\mathrm{a}}$ & $39.15^{\mathrm{a}}$ & $39.28^{\mathrm{a}}$ & $39.17^{\mathrm{a}}$ & \\
& \pm 0.23 & \pm 0.34 & \pm 0.31 & \pm 0.52 & \pm 0.53 & \pm 0.59 & \pm 0.57 & \pm 0.34 & \\
\hline
\end{tabular}

Different letters in the same row indicate significant difference $(\mathrm{P} \leq 0.05)$. 


\section{DISCUSSION}

Apnoea is a common character of Thiopentone anaesthesia (Hall et al., 2006), in this study apnoea occurred in all protocols tested and its duration was exaggerated to a significant levels when the protocol of $\mathrm{TH}+\mathrm{XY}$ was used, this prolongation may be attributed to the effect of Xylazine which was reported to depress the respiratory system (Aithal et al., 1997) while the other pre anaesthetic medications used were known to have minimal effect on the respiratory system (Marntel and Nyman, 1996. Muir and Masonen, 1982), the depressive effect of Xylazine on respiratory centres may potentiate the depressive effect exerted by Thiopentone sodium on respiratory centres hence the significant prolongation of the apnoea duration when this protocols compared with the other protocols used in the study.

The shorter duration of anaesthetic phase resulted from usage of Thiopentone sodium without premedication may be due to the nature of the anaesthetic which classified as an ultra short acting barbiturate which causes a very short period of anaesthesia (Hall et al., 2006)

The significant prolongation of the anaesthesia phase resulted when $\mathrm{TH}+\mathrm{DZ}$ and $\mathrm{TH}+\mathrm{XY}$ were used may be due to the effect of the pre anaesthetic medication used which were classified as hypnotic and sedative and their might be some sort of potentiation of the anaesthetic effect of $\mathrm{TH}$ as a result of using these two pre-anaesthetic medications the potentiation may be mediated by the depressive effect of the two drugs on the CNS.

$\mathrm{XY}$ and DZ are classified as sedative /hypnotic and they lead to excessive depression of CNS more than ACP which is classified as tranquilizer which lead to a CNS depression less than the other two drugs hence the shorter duration of the narcotic and the lateral recumbancy phase caused by the protocol containing the last drug and the protocol containing $\mathrm{TH}$ alone.

Sternal recumbancy phase resulted as $\mathrm{TH}$ anaesthesia without premedication may be due to the fact that the premedicated animals spent a longer duration in the anaesthesia, narcosis and sternal recumbancy phase and when they reach this phase they passed over it very quickly while in case of $\mathrm{TH}$ alone the animal spent a shorter duration of time in the phases preceding this phase so they needed a longer period to pass over this phase.

Induction of anaesthesia with $\mathrm{TH}$ with or without premedication resulted in tachycardia (whether it is significant or non significant) at 
variable times after induction of anaesthesia; this tachycardia persisted in some protocols for the whole period of anaesthesia and disappeared in some. This result is supported by the findings of Rawling and Kolata (1983), Karimi (1987), and Kumar and Sharma (1986).

Induction of anaesthesia with $\mathrm{TH}$ with or without premedication resulted in depression in respiratory rate at different times during the course of anaesthesia and this may be due to the central depressing effect of thiopentone sodium reported be Taylor (1990) in case of TH $+\mathrm{XY}$ the late depression effect observed at 20 minutes after induction of anaesthesia may be attributed to usage of xylazine which also reported to cause respiratory depression.

\section{REFERENCES}

Aithal, H.P.; Amarapal, K.; Paratap, K. and Singh, K.R. (1997): Clinical effect of epidurally administered ketamine and Xylazine in goat. Small ruminant Research. 24: 55 - 64.

Atkinson, R.S.; Rashman, G.B.; and Alfred lee, J. (1987): A synopsis of anaesthesia. $10^{\text {th }}$ ed. Wright, Bristol, London.

Batoul, M.A.E. (1990): Some aspects of stress on liver and thyroid function in goats. M.Sc. Thesis Faculty of Veterinary Science, U. of. K pp. $25-26$.

Hall, L.W. and Clark, K.W. (1982): Veterinary anaesthesia, $8^{\text {th }}$ edition. ELSB and Bailliere and Tindal. London pp. 51-283.

Hall, L.W. and Clark K.W. (1992): Veterinary anaesthesia, $9^{\text {th }}$ edition. Bailliere and Tindal. London pp. 51-283.

Hall, L.W.; Clark, K.W.; and Trim, C.M. (2006): Veterinary anaesthesia, $10^{\text {th }}$ edition. Saunders. Elsevier limited.

Jani, B.M.; Patel, G.R. and Manari, M.N. (1982): Evaluation of propandid in combination with different preanaesthetic agents in dogs. Indian Veterinary Journal, 59: 773-776.

Karimi, A. (1987): Comparison of the effect of two sets of anaesthetic agents on posture, respiratory rate, heart rate, $\mathrm{pH}$, blood gas and acid-base balance in horse. Br. Vet. J. 143 (6): 506-512.

Kelly, W.R. (1984): Veterinary Clinical Diagnosis. $3^{\text {rd }}$ ed. Bailliere and Tindal, London Pp $22-40$.

Kumar, A. and Sharma, A.K. (1986): Thiopentone sodium with or without xylazine premedication in buffaloes. Indian Journal of Animal Science. 56 (10): 1022-1029. 
Marntel, S. and Nyman, G. (1996): Effect of additional premedication on romefidine and ketamine anaesthesia in horse. Acta Veterinaria Scandinavia.37: 3,315-325

Muir, W.W. and Masonen, D.E. (1982): Effect of diazepam, acepromazine, detomidine and Xylazine on thimylal anaesthesia in horses. J. Am. Vet. Med. Assoc. 203(7):1031 1038

Payne, W.J.A. (1994): An introduction to animal husbandry in the tropics. $4^{\text {th }}$ edition. Longman Group. Longman House Burnt Mill, Harlow, Essex CM202 JE, England.

Rawling, C.A. and Kolata, R.J. (1983): Cardiopulmonary effects of Thiopentone lidocaine combination during anaesthesia induction in dogs. Am. J. Vet. Res. 44 (1): 144-149.

$S B A R$ (2000): Statistical Bulletin for Animal Resources. Ministry of Animal Resources. Sudan. 10: 14.

Singh, B. and Kumar, A. (1988): Diazepam as premedication to Thiopentone sodium anaesthesia in goats. Indian Veterinary Journal 65(5): 314-319.

Tamisto, T.; Aroma, U. and Koittilla, K. (1981): The role of Thiopentone and fentanyl in production of balanced anaesthesia. Survey of anaesthesia. 25(2): 93-94.

Taylor, P.M. (1990): The stress response to anaesthesia in ponies under barbiturate anaesthesia. Equine Veterinary Journal 22(5): $307-$ 312. 